\title{
PERTANGGUNGJAWABAN KEUANGAN PARTAI POLITIK YANG BERSUMBER DARI ANGGARAN PENDAPATAN BELANJA NEGARA DAN ANGGARAN PENDAPATAN BELANJA DAERAH
}

\author{
FINANCIAL RESPONSIBILITY OF POLITICAL PARTY OBTAINED FROM STATE \\ BUDGET AND LOCAL GOVERNMENT BUDGET
}

\author{
Songga Aurora Abadi \\ Program Studi Magister Ilmu Hukum Universitas Indonesia \\ Jalan Margonda Raya, Depok \\ email:songgaauroraabadi@gmail.com
}

\begin{abstract}
: the purpose of this article is to describe the procedures for the financial accountability of political parties obtained from the State Budget (APBN) or the Local Government Budget (APBD) and the substance of the political party accountability report. The study method uses sociological juridical with case studies. Data collection uses interviews and documentation studies. Political parties obtain funds sourced from the APBN or APBD according to the number of votes obtained at the national level (DPR), provincial (Provincial DPRD), and city/regency (City/Regency DPRD). The use of funds following regulations must allocate a minimum of $60 \%$ for political education. Political parties must report financial accountability to the government and the public. Supreme Audit Agency (BPK) audit the financial report. The financial report of political parties in the province is transparent. Financial report has been reported to the government and the public by political parties. The report is not yet sufficiently accountable because the use of finance is still not under the party's statutes/by-laws.
\end{abstract}

Keywords: political party finance, party regeneration, political education

\begin{abstract}
Abstrak: tujuan penulisan artikel ini adalah mendeskripsikan prosedur pertanggungjawaban keuangan partai politik yang bersumber dari Anggaran Pendapatan Belanja Negara (APBN) atau Anggaran Pendapatan Belanja Daerah (APBD) dan substansi laporan pertanggungjawaban partai politik. Metode kajian menggunakan yuridis sosiologis dengan studi kasus. Pengumpulan data menggunakan wawancara dan studi dokumentasi. Partai politik memperoleh dana yang bersumber dari APBN atau APBD sesuai jumlah kursi atau suara yang diperoleh pada tingkat nasional (DPR), provinsi (DPRD provinsi), dan kota/kabupaten (DPRD kota/kabupaten). Penggunaan dana sesuai peraturan harus mengalokasikan minimal $60 \%$ untuk pendidikan politik. Partai politik harus membuat laporan pertanggungjawaban keuangan kepada pemerintah dan masyarakat. Laporan keuangan diaudit oleh Badan Pemeriksa Keuangan (BPK). Laporan pertanggungjawaban keuangan partai politik yang ada di provinsi sudah transparan, yaitu sudah melaporkan ke pemerintah dan masyarakat. Laporan belum cukup akuntabel karena penggunaan keuangan masih kurang sesuai dengan landasan partai yang tercantum dalam anggaran dasar/anggaran rumah tangga partai.
\end{abstract}

Kata Kunci : keuangan partai politik, kaderisasi partai, pendidikan politik

\section{PENDAHULUAN}

Kemerdekaan berserikat, berkumpul, serta mengeluarkan pikiran dan pendapat merupakan hak warga negara yang diakui dan dijamin dalam Undang-Undang Dasar Negara Republik Indonesia Tahun 1945. 
Tujuannya adalah untuk mewujudkan cita-cita negara Indonesia yang berdaulat, demokratis, adil dan makmur berdasarkan hukum. Negara sebagai wadah untuk mewujudkan cita-cita yang mulia tersebut di dalamnya terdapat unsur-unsur pembentuknya, yaitu rakyat, wilayah, dan pemerintahan. Rakyat sebagai kekuatan tertinggi dalam demokrasi memiliki peran penting dalam pelaksanaan nilai-nilai demokrasi. Indonesia yang termasuk dalam negara kepulauan memiliki berbagai macam suku, agama, budaya, dan ras yang memerlukan suatu wadah untuk kelangsungan hidupnya.

Dinamika dan perkembangan masyarakat yang majemuk menuntut peningkatan peran, fungsi, dan tanggung jawab semua pihak, salah satunya adalah partai politik yang merupakan komponen pelaksana kehidupan demokrasi. Kehadiran partai politik merupakan sarana partisipasi politik masyarakat untuk mewujudkan cita-cita nasional, menjaga keutuhan negara kesatuan Republik Indonesia, mengembangkan kehidupan demokrasi berdasarkan Pancasila dengan menjunjung tinggi kedaulatan rakyat untuk mewujudkan kesejahteraan bagi seluruh Rakyat Indonesia (Fokusmedia, 2009). Di negara yang menganut sistem pemerintahan demokrasi maupun yang sedang membangun, partai politik menjadi sarana penghubung antara rakyat dan pemerintah. Salah satu prinsip demokrasi adalah pemerintahan dipimpin mayoritas yang merupakan perwakilan rakyat melalui partai politik melalui pemilihan umum. Partai politik dapat dikatakan sebagai kendaraan politik karena melalui partai politik rakyat berhak menentukan calon pemimpin dan menentukan kebijakan umum (Cangara, 2011).

Partai politik adalah suatu organisasi yang bertujuan mencapai dan memelihara pengawasan terhadap pemerintahan atau juga dapat diartikan sebagai koalisi yang cukup stabil, abadi, dan sering konflik kepentingan, diselenggarakan untuk menggalang dukungan dalam pemilihan untuk mengontrol pembuatan kebijakan (Nimmo, 2011). Partai politik dapat didefinisikan sebagai kelompok anggota yang terorganisasi secara rapi, stabil, dipersatukan, dan dimotivasi dengan ideologi tertentu, yang berusaha mencari dan mempertahankan kekuasaan dalam pemerintahan melalui pemilihan umum untuk melaksanakan alternatif kebijakan umum yang dirancang (Surbakti, 1992). Undang-Undang Nomor 2 Tahun 2011 tentang Perubahan Atas Undang-Undang Nomor 2 Tahun 2008 tentang Partai Politik pada Pasal 1 ayat (1) menyatakan bahwa partai politik adalah organisasi yang bersifat nasional dan dibentuk oleh sekelompok warga negara Indonesia secara sukarela atas dasar kesamaan kehendak dan cita-cita untuk memperjuangkan dan membela kepentingan politik anggota masyarakat, bangsa dan negara, serta memelihara keutuhan negara kesatuan Republik Indonesia berdasarkan Pancasila dan Undang-Undang Dasar Negara Republik Indonesia Tahun 1945.

Reformasi mendorong lahirnya partai politik baru. Peningkatan partisipasi politik masyarakat dalam kebutuhan berserikat, berekspresi, dan berkumpul harus disambut dengan baik. Pasca reformasi, kontestan politik bangsa Indonesia semakin berkembang pesat. Partai politik hadir untuk memperbaiki sistem ekonomi dan politik bangsa Indonesia yang kurang berpihak kepada rakyat, antara lain disparitas kelas sosial yang tinggi, praktik korupsi, kolusi, nepotisme, demoralisasi, tindakan asusila, politik uang, diskriminasi, ketidakbebasan berekspresi, kemiskinan, upah yang rendah, gizi buruk, pengangguran, pendidikan mahal, eksploitasi sumber daya alam, dan hutang luar negeri. Partai politik cenderung menjadi alat kekuasaan yang memihak kepentingan pribadi, korporasi, dan oligarki kekuasaan. Berkembangnya partisipasi politik masyarakat dapat menjadi harapan dalam perjuangan politik dengan semangat perubahan, transformasi sosial, perkembangan berbagai ide, konsep dan 
gagasan, serta reformasi pemerintahan yang lebih baik.

Hadirnya partai politik sebagai wadah demokrasi setiap warga negara mampu membuktikan dan menjelaskan secara kongkrit bahwa rakyat sebagai pemegang kekuasaan tertinggi negara dapat merumuskan dan berpartisipasi dalam rangka mewujudkan cita-cita rakyat Indonesia melalui partai politik. Partai dan sistem kepartaian adalah infrastruktur politik yang mengisi lembagalembaga negara serta menyelenggarakan fungsi, tugas, dan wewenang yang melekat di dalamnya (suprastruktur politik). Implikasi sistem kepartaian terhadap penyelenggaraan pemerintahan negara dapat berupa stabil atau tidak stabilnya serta demokratis atau tidak demokratisnya sistem politik (Firdaus, 2015).

Kehadiran partai politik adalah hasil pertarungan ideologi antar kekuatan yang ada dalam masyarakat yang muncul sebagai representasi kepentingan warga negara. Hal ini merupakan konsekuensi logis dari sistem negara hukum demokrasi. Partai politik adalah suatu wadah organisasi yang memungkinkan kehidupan publik tetap berlangsung. Permasalahan yang muncul adalah apabila partai politik tidak dapat berjalan dengan baik. Menurut Maarif, politik yang dijalankan saat ini dapat menyebabkan krisis kepemimpinan (Sunaryo, 2014). Power tends to corrupt dan ethics has no place in politics merupakan dua adagium klasik dalam kehidupan politik yang berusaha memperlihatkan mudahnya praktik-praktik politik terperangkap dalam kecenderungan subordinasi kepentingan pribadi atas kepentingan rakyat.

Konsepsi dan gagasan untuk menata partai politik sesungguhnya merupakan agenda yang mendesak untuk meredam ketidakstabilan politik. Pembentukan partai politik harus memiliki fungsi dan peran yang mampu menjaga eksistensinya sebagai jembatan penghubung dalam memperjuangkan aspirasi rakyat. Pasal
11 ayat (1) dan ayat (2) Undang-Undang Nomor 2 tahun 2011 tentang Perubahan Atas Undang-Undang Nomor 2 Tahun 2008 tentang partai politik menyatakan partai politik berfungsi sebagai sarana: (a) pendidikan politik bagi masyarakat agar sadar terhadap hak dan kewajibannya dalam kehidupan bermasyarakat, berbangsa, dan bernegara, (b) penciptaan iklim yang kondusif bagi persatuan dan kesatuan bangsa Indonesia untuk kesejahteraan masyarakat, (c) penyerap, penghimpun, dan penyalur aspirasi politik masyarakat dalam merumuskan serta menetapkan kebijakan negara, (d) partisipasi politik warga negara Indonesia, dan (d) rekrutmen politik dalam proses pengisian jabatan politik melalui mekanisme demokrasi dengan mempertahankan kesetaraan dan keadilan gender.

Pasal 11 Undang-Undang Nomor 2 Tahun 2011 tentang Partai Politik mengamanatkan perlunya pendidikan politik sebagai salah satu sarana mewujudkan keadilan dan kesetaraan gender yang ditujukan untuk meningkatkan kesadaran akan hak dan kewajiban, meningkatkan partisipasi politik dan inisiatif warga negara, serta meningkatkan kemandirian dan kedewasaan dalam kehidupan berbangsa dan bernegara. Perspektif bahwa partai politik adalah salah satu unsur sistem ketatanegaraan Indonesia sebagai penentu kebijakan, diharapkan dapat memainkan fungsi dan peranannya dengan baik sesuai dengan hukum dan peraturan perundangundangan yang berlaku.

Pemerintah melalui peraturan undangundangan memberikan bantuan keuangan kepada partai politik untuk pembiayaan pendidikan politik bagi anggota partai politik maupun masyarakat. UndangUndang Nomor 2 Tahun 2011 tentang Perubahan Atas Undang-Undang Nomor 2 Tahun 2008 Pasal 34 ayat (3) menyatakan bahwa bantuan keuangan untuk partai politik yang berasal dari APBN atau APBD diberikan secara proporsional berdasarkan 
jumlah kursi yang ada di DPR RI, DPRD provinsi, dan DPRD kabupaten/kota. Pasal 34 ayat (3a) menyatakan bahwa bantuan keuangan diberikan untuk pendidikan politik bagi anggota partai politik dan masyarakat. Bantuan keuangan diberikan dengan tujuan untuk menjaga stabilitas dan kemandirian partai politik agar terhindar dari kepentingan kelompok-kelompok tertentu yang memberikan sumbangan. Bantuan yang sudah diberikan harus dapat dipertanggungjawabkan terhadap negara dalam hal penggunaan keuangan sebagaimana diatur dalam Pasal 39 ayat (1) UndangUndang Nomor 2 Tahun 2011 tentang Perubahan Atas Undang-Undang Nomor 2 Tahun 2008 tentang Partai Politik.

Bantuan keuangan yang diberikan negara didasarkan pada jumlah perolehan suara pada pemilihan umum. Alokasi anggaran dari APBN/APBD sebagaimana penjelasan lebih lanjut, yang diatur dalam Peraturan Pemerintah Nomor 83 Tahun 2012 pasal 9 ayat (1) dan ayat (3) tentang Bantuan Keuangan kepada Partai Politik digunakan sebagai dana penunjang kegiatan pendidikan politik dan operasional sekretariat partai politik. Bantuan keuangan kepada partai politik digunakan untuk melaksanakan pendidikan politik paling sedikit $60 \%$ dari total dana yang diperoleh.

Peraturan Pemerintah Nomor 83 Tahun 2012 Pasal 10 ayat (2) tentang Bantuan Keuangan kepada Partai Politik mengatur tentang ruang lingkup penyelenggaraan pendidikan politik dengan menyusun program pendidikan secara periodik. Materi pendidikan politik terdiri atas: (a) pendalaman mengenai empat pilar yaitu Pancasila, UUD NRI Tahun 1945, Bhinneka Tunggal Ika, Negara Kesatuan Republik Indonesia (NKRI), (b) pemahaman mengenai hak-hak dan kewajiban warga negara Indonesia dalam membangun etika dan budaya politik, dan (c) pengkaderan anggota partai politik secara berjenjang dan berkelanjutan.
Kebijakan pendanaan partai politik melalui APBN/APBD harus sesuai prosedur hukum dan perundang-undangan yang berlaku sehingga perlu dikaji dan diperhatikan agar tidak terjadi penyelewengan yang merugikan negara. Evaluasi kinerja partai politik adalah suatu kepentingan yang mendesak, demi terwujudnya kehidupan yang dicitacitakan oleh bangsa Indonesia. Berdasarkan permasalahan dan latar belakang yang telah diuraikan, tulisan ini bertujuan membahas mekanisme pertanggungjawaban keuangan partai politik yang menggunakan keuangan negara.

Konsep kedaulatan rakyat atau disebut demokrasi terdiri atas dua kata yang berasal dari bahasa Yunani, yakni demos artinya rakyat atau orang banyak dan kratos artinya kekuasaan, jadi demokrasi dalam bahasa Yunani berarti kekuasaan berada di tangan rakyat. Teori demokrasi atau kedaulatan rakyat berpandangan bahwa rakyat yang dianggap sebagai pemilik dan pemegang kekuasaan tertinggi dalam suatu negara (Kusnardi \& Harmaily, 1998). Kedaulatan rakyat atau biasa disebut dengan istilah demokrasi menghendaki rakyat yang menentukan cara pemerintahan diselenggarakan, tetapi hal tersebut sulit dilaksanakan karena kompleksitas keadaan sehingga kedaulatan rakyat dilaksanakan melalui sistem perwakilan (Asshiddiqie, 2017). Demokrasi berarti kekuasaan rakyat, yakni kekuasaan yang bersumber dari, oleh, dan untuk rakyat (government of the people, by the people, and for the people). Dengan demikian, demokrasi bagi Lincoln adalah a system where no man is good enough to govern another man without that other's consent. Kalimat tersebut menjelaskan bahwa demokrasi merupakan sistem yang tidak seorang pun manusia cukup baik untuk memerintah manusia lainnya tanpa persetujuan mereka.

Negara demokrasi dapat dilaksanakan dengan mengarahkannya pada pemberdayaan suprastruktur dan infrastruktur politik agar 
menjadi wahana perjuangan mewujudkan dan melaksanakan demokrasi dalam arti sesungguhnya, bukan sekedar formalitas (Manan, 2004). Demokrasi bukan merupakan variabel mandiri, tetapi keberadaannya sangat dipengaruhi situasi nilai yang sedang tumbuh berkembang di tengah masyarakat yang hendak dilayani (Firdaus, 2015).

Negara hukum demokrasi adalah usaha untuk menata struktur kelembagaan demokrasi yang memungkinkan terbentuknya bangunan mekanisme dan prosedur bagi tegak dan terlindungnya martabat manusia secara tertib, rasional, dan proporsional. Kebebasan dan stabilitas berlangsungnya suatu negara dapat diwujudkan dan dibatasi melalui demokrasi konstitusional, yang termanifestasikan dalam negara hukum demokrasi. Sebuah konsep negara hukum demokrasi adalah negara yang menggunakan konstitusi untuk mewujudkan kehendak rakyat atau kedaulatan rakyat (Firdaus, 2015). Konstitusi merupakan manifestasi tertinggi kedaulatan rakyat yang melandasi seluruh aktivitas penyelenggaraan pemerintahan negara, baik yang memerintah maupun yang diperintah.

Secara etimologi pertanggungjawaban berasal dari kata tanggung jawab. KBBI mengartikan tanggung jawab sebagai keadaan wajib menanggung segala sesuatu (Departemen Pendidikan dan Kebudayaan, 1998). Di dalam kamus hukum Black Law Dictionary mencantumkan tiga kata yang dapat diasosiasikan dengan istilah pertanggungjawaban yaitu responsibility, liability, dan accountability.

Institusi partai politik berkaitan erat dengan istilah akuntabilitas, dijelaskan dalam Webster Dictionary bahwa keadaan bertanggung jawab dalam makna accountable, responsible, atau liable (Keclime et al, 1983). Dalam bahasa Belanda dijumpai istilah veraantwardelijk sebagai padanan kata tanggung jawab. Andrea memaknai veraantwardelijk sebagai kewajiban untuk memikul pertanggungjawaban hingga menanggung kerugian (apabila dituntut) dalam kaitan dengan hukum maupun dalam administrasi.

Tanggung jawab bermakna suatu tanggungan yang diberikan sebagai sebuah pertanggungjawaban yang harus dipenuhi oleh sesuatu yang diberi tanggung jawab tersebut. Apabila dihubungkan dengan Hans Kelsen dalam teori tradisional, terdapat dua macam pertanggungjawaban yang dibedakan yaitu pertanggungjawaban berdasarkan kesalahan dan pertanggungjawaban mutlak (Asshiddiqie \& Safa'at, 2012).

Pertanggungjawaban harus memenuhi dua dimensi yaitu dimensi informatif (invormativeness) dan pengungkapan (disclosure). Indikator informatif adalah tepat waktu, memadai, jelas, akurat, dapat diperbandingkan, dan mudah diakses.

Laporan keuangan atau laporan lainnya harus disajikan tepat waktu agar dapat digunakan sebagai dasar pengambilan keputusan ekonomi, sosial, politik serta untuk menghindari tertundanya pengambilan keputusan tersebut. Memadai artinya penyajian laporan keuangan harus sesuai dengan prinsip akuntansi yang berlaku umum di Indonesia mencakup dimuatnya pengungkapan informasi yang memadai atas hal-hal materiel. Jelas, informasi harus jelas sehingga dapat dipahami dan tidak menimbulkan kesalahpahaman. Akurat, informasi harus bebas dari kesalahan dan tidak menyesatkan bagi pengguna yang menerima dan memanfaatkan informasi tersebut. Akurat juga berarti informasi harus jelas mencerminkan maksudnya. Dapat diperbandingkan, maksudnya laporan keuangan harus dapat diperbandingkan antara periode waktu atau dengan instansi yang sejenis. Dengan demikian, daya banding berarti bahwa laporan keuangan dapat dipergunakan untuk membandingkan kinerja organisasi dengan organisasi lain yang sejenis. Informasi harus mudah diakses oleh semua pihak. 
Pengungkapan kepada masyarakat atau publik (stakeholders) atas aktivitas dan kinerja finansial memiliki beberapa indikator, yaitu: (a) tampilan atau keadaan secara utuh kondisi keuangan organisasi atau organisasi selama periode atau kurun waktu tertentu, (b) susunan pengurus, komponenkomponen (unit kerja) dalam organisasi/ struktur organisasi yang menunjukkan adanya pembagian kerja berdasarkan fungsi atau kegiatan yang berbeda-beda yang diintegrasikan (ada koordinasi), (c) bentuk perencanaan dan hasil dari kegiatan adalah serangkaian tindakan untuk mencapai hasil yang diinginkan.

Transparansi tidak hanya memberikan laporan mengenai keuangan, tetapi lebih berkaitan dengan pertanggungjawaban partai politik terhadap penggunaan keuangan negara. Partai politik harus memperhatikan asas transparansi karena asas hukum menunjukkan adanya tuntutan etis dan nilai-nilai (Rahardjo, 2006). Substansi dari kinerja partai politik dapat diukur dari transparansi partai politik menggunakan keuangan negara.

Pertanggungjawaban keuangan partai politik yang bersumber dari APBN/APBD merupakan bentuk pertanggungjawaban sebagai akuntabilitas. Pada awalnya istilah akuntabilitas diterapkan untuk mengukur penetapan dan penggunaan dana publik secara legal (Rooseno, 2014). Akuntabilitas merupakan bentuk kewajiban penyedia penyelenggaraan kegiatan publik untuk menjelaskan segala hal yang menyangkut langkah seluruh keputusan dan proses yang dilakukan, serta pertanggungjawaban terhadap hasil dan kinerjanya (Lukito, 2014). Lembaga Administrasi Negara (LAN) dan Badan Pemeriksa Keuangan (BPK) menyatakan bahwa pelaksanaan akuntabilitas harus memperhatikan lima prinsip, yaitu: (a) komitmen dari pimpinan dan seluruh staf untuk melakukan pengelolaan pelaksanaan misi agar akuntabel, (b) sistem yang dapat menjamin penggunaan sumber daya secara konsisten dengan peraturan perundang-undangan, (c) mewujudkan tingkat pencapaian tujuan dan sarana yang telah ditetapkan, (d) berorientasi kepada pencapaian visi dan misi serta manfaat yang telah diperoleh, (e) jujur, obyektif, transparan, dan inovatif sebagai katalisator perubahan dalam bentuk pemutakhiran metode dan teknik pengukuran kinerja dan penyusunan laporan akuntabilitas.

Pertanggungjawaban keuangan partai politik yang bersumber dari keuangan negara termasuk akuntabilitas vertikal karena mempertanggungjawabkan keuangan kepada negara melalui Badan Pemeriksa Keuangan (BPK). Pertanggungjawaban keuangan partai politik dilihat dari segi finansial berarti menyusun akuntabilitas finansial secara sistematis karena berhubungan dengan penggunaan uang publik atau uang negara yang harus dilakukan secara ekonomis, efisisen, dan efektif. Prinsip pertanggungjawaban akuntabilitas tidak hanya berdasarkan laporan keuangan saja tetapi juga substansinya yaitu berkaitan dengan akuntabilitas program, ketercapaian tujuan, dan alternatif program yang memberikan hasil optimal. Indikator akuntabilitas program adalah hasil dari program yang dijalankan, kesesuaian antara target dan pencapaian program, serta pernyataan yang jelas mengenai tujuan dan sasaran dari program (Halim \& Syam, 2012).

\section{METODE}

Kajian ini menggunakan pendekatan penelitian yuridis sosiologis yaitu menelaah fenomena yang terjadi di lapangan dan mendasarkannya pada peraturan perundangundangan yang berlaku (Soekanto, 1984). Jenis penelitian yang digunakan adalah studi kasus. Pengumpulan data menggunakan wawancara dan studi dokumentasi. Objek kajian adalah pertanggungjawaban keuangan partai politik yang menyangkut mekanisme pertanggungjawaban keuangan dan substansi 
pertanggungjawaban keuangan partai politik yang bersumber dari APBN/APBD. Subyek kajian adalah partai politik di Provinsi Banten, yaitu Dewan Pimpinan Daerah Partai Demokrasi Indonesia Perjuangan (PDIP) Banten dan Dewan Pimpinan Wilayah (DPW) Partai Persatuan Pembangunan (PPP) Banten.

\section{HASIL DAN PEMBAHASAN}

Prosedur Pertanggungjawaban Keuangan Partai Politik yang Bersumber dari Anggaran Pendapatan Belanja Negara dan Anggaran Pendapatan Belanja Daerah

Partai politik merupakan pilar penentu tegaknya negara hukum yang demokrastis. Partai politik berperan untuk menciptakan harmonisasi di lingkungan masyarakat, menghimpun berbagai aspirasi, merumuskan suatu gagasan untuk menentukan proses kebijakan publik yang mengarah kepada kesejahteraan hajat hidup rakyat Indonesia. Eksistensi partai politik diakui dalam konstitusi negara. Penentuan kepala pemerintahan dan kepala negara harus melalui partai politik. Pasal 8 ayat (3) UUD NRI 1945 menyatakan bahwa dalam hal kekosongan kekuasaan pemerintahan, partai politik memiliki peranan menentukan kebijakan. Pasal 22E ayat (3) tentang pemilihan umum menyatakan bahwa pemilihan anggota DPR dan DPRD harus diusulkan melalui partai politik. Hal tersebut menunjukkan pentingnya keberadaan partai politik. Partai politik harus mengabdi kepada konstituennya yaitu rakyat, proses dalam pengusungan setiap yang dicalonkan adalah para kader terbaik setiap partai yang merupakan bagian dari rakyat. Partai politik memiliki kewajiban membina dan mengembangkan kader-kadernya agar dapat menjalankan fungsinya sebagai penyalur aspirasi rakyat.

Undang-Undang Nomor 2 Tahun 2011 tentang perubahan Undang-Undang Nomor 2 Tahun 2008 tentang Partai Politik menegaskan bahwa partai politik adalah bentuk komitmen negara menyusun mekanisme kepartaian yang baik. Dalam menjalankan tugas dan fungsinya partai politik membutuhkan alokasi anggaran yang memadai dan pemerintah bertanggung jawab memberikan bantuan keuangan kepada setiap partai politik peserta pemilu melalui APBN dan APBD (Pasal 12 huruf $\mathrm{k}$ dan pasal 34 UU Nomor 2 Tahun 2011). Tujuan diberikannya bantuan keuangan kepada partai politik melalui APBN dan APBD agar partai politik sungguh-sungguh sebagai wadah aspirasi rakyat, penyerap, penghimpun dan penyalur ekspresi politik setiap rakyat.

Partai politik berkewajiban untuk memberikan pendidikan politik kepada setiap elemen rakyat Indonesia dan pencerdasan dalam rangka membangun proses partisipasi politik masyarakat. Partai politik harus dapat mempertanggungjawabkan keuangan secara prosedural kepada negara. Bantuan keuangan partai politik diberikan secara proporsional kepada partai politik yang mendapatkan kursi di DPR, DPRD Provinsi, dan DPRD Kabupaten/Kota yang penghitungannya berdasarkan jumlah perolehan suara. Artinya setiap bantuan keuangan tersebut dapat diberikan kepada partai politik yang menjadi peserta pemilu yang memperoleh kursi.

Alur dan mekanisme bantuan keuangan diatur dalam Pasal 2 ayat (1) Peraturan Pemerintah Nomor 83 Tahun 2012 tentang Perubahan Atas Peraturan Pemerintah Nomor 5 Tahun 2009 tentang Bantuan Keuangan kepada Partai Politik. Bantuan keuangan diperoleh sesuai wilayahnya masing-masing, diberikan melalui APBN/ APBD melalui pemerintah/pemerintah daerah. Bantuan keuangan yang diberikan melalui APBN di tingkat pusat diberikan kepada partai politik yang mendapatkan kursi di DPR, bantuan keuangan yang bersumber dari APBD diberikan kepada partai politik yang mendapatkan kursi di DPRD Provinsi, dan bantuan keuangan 
APBD kabupaten/kota diberikan kepada partai politik yang mendapatkan kursi di DPRD kabupaten/kota.

Pengajuan bantuan keuangan dilakukan dengan mengajukan permohonan secara tertulis kepada pemerintah/pemerintah daerah. Mekanisme pengajuan bantuan keuangan tersebut diatur lebih rinci berdasarkan Peraturan Menteri Dalam Negeri Nomor 77 Tahun 2014 tentang Pedoman Tata Cara Penghitungan, Penganggaran dalam APBD, dan Tertib Administrasi Pengajuan, Penyaluran, dan Laporan Pertanggungjawaban Penggunaan Bantuan Keuangan Partai Politik. Pengurus partai politik menyampaikan surat permohonan bantuan keuangan di tingkat pusat kepada menteri dalam negeri melalui direktur jenderal kesatuan bangsa dan politik. Surat permohonan ditandatangani oleh ketua umum dan sekretaris jenderal atau sebutan lainnya yang terdaftar di Kementerian Hukum dan Hak Asasi Manusia. Surat permohonan menggunakan kop surat dan cap stempel partai politik serta melampirkan: (a) dua rangkap fotocopi akta notaris pendirian yang memuat anggaran dasar dan anggaran rumah tangga, (b) fotokopi legalisir susunan pengurus yang terdaftar dan disahkan oleh Kementerian Hukum dan Hak Asasi Manusia, (c) fotokopi nomor pokok wajib pajak, (d) menyerahkan nomor rekening, (e) surat autentifikasi hasil penetapan perolehan kursi dan suara hasil pemilihan umum DPR RI yang dilegalisir oleh ketua atau wakil ketua atau sekretaris jenderal Komisi Pemilihan Umum, (e) rencana penggunaan dana dengan mencantumkan paling sedikit $60 \%$ untuk pendidikan politik, (f) surat pernyataan ketua partai politik yang menyatakan bertanggung jawab secara formal dan materiel dalam penggunaan anggaran.

Mekanisme pengajuan bantuan oleh pengurus di tingkat daerah diatur dalam Peraturan Pemerintah Nomor 83 Tahun 2012 tentang Perubahan Atas Peraturan Pemerintah Nomor 5 tahun 2009 tentang Bantuan Keuangan kepada Partai Politik dan Peraturan Menteri Dalam Negeri Nomor 77 Tahun 2014 tentang Pedoman Tata Cara Penghitungan, Penganggaran Dalam APBD, dan Tertib Administrasi Pengajuan, Penyaluran, dan Laporan Pertanggungjawaban Penggunaan Bantuan Keuangan Partai Politik. Pengajuan bantuan keuangan harus diajukan oleh pengurus di tingkat daerah dengan mengajukan surat permohonan kepada gubernur, yang ditandatangani ketua dan wakil atau sekretaris, mencantumkan syarat-syarat yang harus dipenuhi berdasarkan peraturan. Partai Demokrasi Indonesia Perjuangan Provinsi Banten tahun 2015 mendapatkan dana sebesar Rp367.620.650,00 (PDIP, 2015b). Partai Persatuan Pembangunan (PPP) Provinsi Banten tahun anggaran 2014 mendapatkan bantuan dana sebesar Rp111.263.243,00 (PPP, 2015).

Partai politik termasuk badan publik yang diatur dalam perundang-undangan. Definisi badan publik menurut undangundang adalah lembaga legislatif, eksekutif, yudikatif, dan badan lain yang fungsi dan tugas pokoknya berkaitan dengan penyelenggaraan negara, yang sebagian atau seluruh dananya bersumber dari APBN/ APBD, atau organisasi non pemerintah sepanjang sebagian atau seluruh dananya bersumber dari APBN/APBD, sumbangan masyarakat, dan/atau sumbangan luar negeri. Partai politik termasuk ke dalam badan publik yang harus akuntabel dan transparan. Akuntabilitas adalah bentuk pertanggungjawaban terhadap segala bentuk pengelolaan dan manajerial. Transparan adalah terbuka mempublikasikan informasi atau data-data yang dibutuhkan sesuai ketentuan hukum. Transparansi berarti keterbukaan dan kejujuran kepada masyarakat berdasarkan pertimbangan bahwa masyarakat memiliki hak untuk mengetahui secara terbuka dan menyeluruh atas pertanggungjawaban pemerintah dalam sumber daya yang telah dipercayakan kepadanya.

Laporan bantuan keuangan DPD PDIP Banten tahun anggaran 2016 sudah 
sesuai dengan prosedur yang diatur oleh Peraturan Menteri Dalam Negeri dan Peraturan BPK. Bantuan keuangan DPD PDIP Banten adalah Rp367.620.650,00. Alokasi untuk pendidikan politik sebesar Rp255.424.000,00 (69,48\%) dan sisanya untuk kesekretariatan, berarti telah sesuai dengan peraturan yaitu pendidikan politik minimal 60\%. Laporan pertanggungjawaban keuangan sudah diaudit oleh BPK. Sisa dana digunakan untuk kebutuhan operasional kesekretariatan.

Bantuan keuangan yang bersumber dari APBD kepada DPW PPP Banten adalah Rp111.263.243,00 yang digunakan untuk pendidikan politik sebesar Rp72.780.000,00 $(65,41 \%)$ dan sisanya untuk kebutuan kesekretariatan. Hal tersebut menunjukkan bahwa penggunaan keuangan sudah sesuai dengan peraturan yang ada karena dana untuk pendidikan politik lebih dari $60 \%$.

Hasil laporan pertanggungjawaban keuangan partai politik yang bersumber dari APBD dan telah diaudit oleh BPK tersebut, secara prosedur sudah dilaksanakan sesuai amanat dari peraturan perundang-undangan yang berlaku yaitu Undang-Undang Nomor 2 Tahun 2011 tentang Perubahan Atas Undang-Undang Nomor 2 Tahun 2008 tentang Partai Politik. Kedua partai politik cukup transparan karena sudah memublikasikan kepada masyarakat mengenai laporan pertanggungjawaban bantuan keuangan disertai bukti-bukti penggunaan keuangan. Akuntabilitas laporan pertangungjawaban keuangan masih rendah karena kegitan yang dilaksanakan terkesan formalitas belaka, cenderung hanya menggugurkan kewajiban, khususnya dalam melaksanakan pendidikan politik kepada anggota dan masyarakat.

Bantuan keuangan lebih banyak untuk pendidikan politik yang hanya diselenggarakan untuk agenda-agenda yang tidak substansial. Kegiatan kurang memiliki dampak yang signifikan, khususnya dalam pengelolaan program pendidikan politik. Undang-Undang Nomor 2 Tahun 2011 tentang Perubahan
Atas Undang-Undang Nomor 2 Tahun 2008 tentang Partai Politik menyatakan banhwa tujuan diselenggarakannya pendidikan politik adalah meningkatkan kesadaran hak dan kewajiban, meningkatkan partisipasi politik, meningkatkan kemandirian, kedewasaan, dan membangun karakter bangsa dalam rangka memelihara persatuan dan kesatuan bangsa. Penyelenggaraan pendidikan politik harus diarahkan pada agenda-agenda partai politik yang berkaitan dengan pemahaman kehidupan berbangsa dan bernegara, membangun relasi sosial masyarakat yang sadar akan hak dan kewajibannya dalam membangun etika politik, serta menyelenggarakan pengaderan anggota partai politik secara berjenjang dan berkelanjutan (Pasal 34 UU Nomor 2 Tahun 2011).

Substansi Pertanggungjawaban Keuangan Partai Politik yang Bersumber dari Anggaran Pendapatan Belanja Negara dan Anggaran Pendapatan Belanja Daerah

Demokrasi menjadi simbol perjuangan setiap bangsa yang berusaha mengakhiri tirani otoriterisme (Cangara, 2011). Hal tersebut dapat dilihat dengan banyaknya partai politik atau organisasi kemasyarakatan yang menggadang demokrasi sebagai platform atau ideologinya. Partai politik memiliki peran penting dalam upaya negara mencapai tujuannya yaitu menyejahterakan rakyatnya. Partai politik menjadi sangat penting di era demokrasi karena menjadi perantara antara masyarakat dengan pemerintah. Sebagai organisasi dalam masyarakat, partai politik menyerap, merumuskan, dan menindaklanjuti berbagai kepentingan masyarakat. Partai politik wajib menyampaikan dan mendesak kepentingan masyarakat untuk dibuat menjadi kebijakan pemerintah (Supriyanto \& Wulandari, 2012).

Undang-Undang Nomor 2 Tahun 2011 tentang Perubahan Atas Undang-Undang Nomor 2 tahun 2008 tentang Partai Politik dalam Pasal 13 mengatur tentang kewajiban partai politik, yaitu: (a) mengamalkan 
Pancasila, melaksanakan Undang-Undang Dasar Negara Republik Indonesia Tahun 1945, dan peraturan perundang-undangan, (b) memelihara dan mempertahankan keutuhan Negara Kesatuan Republik Indonesia, (c) berpartisipasi dalam pembangunan nasional, (d) menjunjung tinggi supremasi hukum, demokrasi, dan hak asasi manusia, (e) melakukan pendidikan politik dan menyalurkan aspirasi politik anggotanya, (f) menyukseskan penyelenggaraan pemilihan umum, (g) melakukan pendaftaran dan memelihara ketertiban data anggota, (h) membuat pembukuan, memelihara daftar penyumbang dan jumlah sumbangan yang diterima, serta terbuka kepada masyarakat, (i) menyampaikan laporan pertanggungjawaban penerimaan dan pengeluaran keuangan yang bersumber dari dana APBN dan APBD secara berkala satu tahun sekali kepada pemerintah setelah diperiksa oleh BPK, (j) memiliki rekening khusus dana kampanye pemilihan umum, dan (k) menyosialisasikan program partai politik kepada masyarakat. Partai politik memiliki fungsi utama yaitu mendapatkan dan mempertahankan kekuasaan untuk mewujudkan program berdasarkan ideologi partai. Fungsi partai politik ada lima, terdiri atas komunikasi politik, sosialisasi politik, partisipasi politik, rekrutmen politik, dan pengatur konflik (Budiardjo, 2000).

Partai politik sebagai organisasi yang menyalurkan kepentingan publik harus memiliki program-program perjuangan yang mengarah pada perwujudan suatu kewajiban-kewajiban yang sudah diatur dalam undang-undang. Partai politik terlibat dalam menentukan kebijakan publik untuk menciptakan pemerintahan yang baik (good governance) dan kesejahteraan bagi seluruh rakyat (welfare state). Alokasi anggaran yang memadai terhadap bantuan keuangan dari negara adalah salah satu upaya negara dalam menjaga stabilitas partai.

Pasal 23 UUD NRI 1945 menjelaskan bahwa anggaran pendapatan dan belanja negara sebagai wujud dari pengelolaan keuangan negara dilaksanakan secara terbuka dan bertanggung jawab untuk sebesarbesarnya kemakmuran rakyat. Artinya segala sesuatu yang menyangkut keuangan negara pada hakikatnya berasal dari rakyat yang penggunaannya harus kembali untuk kepentingan rakyat, termasuk partai politik. Pertanggungjawaban keuangan diukur berdasarkan angka keuangan dan substansi pertanggungjawaban harus dapat diukur dari persepektif kinerja partai.

Kinerja partai politik dapat diukur dari pertanggungjawaban penggunaan keuangan, laporan hasil dari program yang dijalankan, kesesuaian antara target dan pencapaian program, dan pernyataan yang jelas mengenai tujuan dan sasaran dari program. Akuntabilitas berkaitan dengan pelaksanaan fungsi dan perannya sesuai dengan peraturan yang berlaku.

Partai politik yang berada di provinsi mengalami kesulitan dalam melaksanakan amanat undang-undang mengenai penggunaan bantuan keuangan dari APBD, khususnya pendidikan politik karena tingkat kesadaran sosial, budaya, ekonomi, politik masyarakat masih rendah. Faktor ekonomi yang masih rendah juga memengaruhi terhadap partisipasi politik masyarakat. Masyarakat harus mendapatkan hak sipil, politik, ekonomi, sosial, dan budaya.

Partai politik memiliki anggaran dasar dan anggaran rumah tangga yang menjadi landasan filosofis sesuai dengan cita-cita ideologisnya untuk mewujudkan tujuan nasional. Hal yang paling fundamental adalah proses kaderisasi di internal partai. Kaderisasi secara substansial sangat penting untuk mewujudkan program perjuangan partai. Undang-Undang Nomor 2 Tahun 2011 tentang Perubahan Atas UndangUndang Nomor 2 Tahun 2008 tentang Partai Politik mengatur mengenai bantuan keuangan untuk pendidikan politik yang mencakup proses rekrutmen yaitu kaderisasi. Kesuksesan institusi organisasi dapat diukur dari keberhasilannya dalam proses kaderisasi 
internal karena wujud dari keberlanjutan organisasi adalah adanya kader-kader yang memiliki kapabilitas dan komitmen yang tinggi terhadap partai.

Penjelasan pada Pasal 86 Anggaran Dasar PDIP mengenai tugas dan fungsi pendidikan politik adalah: (a) menanamkan dan menyebarluaskan ajaran Bung Karno, (b) meningkatkan kesadaran hak dan kewajiban anggota partai dalam kehidupan bermasyarakat, berbangsa, dan bernegara, (c) meningkatkan partisipasi politik dan inisiatif masyarakat dalam kehidupan bermasyarakat, berbangsa, dan bernegara, dan (d) meningkatkan kemandirian, kedewasaan, dan membangun karakter bangsa dalam rangka memelihara persatuan dan kesatuan bangsa (PDIP, 2015a).

Pasal 87 ayat (1) Anggaran Dasar PDIP mengenai kaderisasi menjelaskan bahwa kaderisasi partai dilaksanakan secara berjenjang dan terpadu di bawah pengawasan DPP Partai. Tingkatan kaderisasi menurut ayat (2) ada tiga, yaitu kaderisasi tingkat pratama, kaderisasi tingkat madya, dan kaderisasi tingkat utama. Pasal 80 ayat (1) Anggaran Rumah Tangga PDIP menjelaskan pendidikan politik partai dilaksanakan melalui kegiatan penanaman dan penyebarluasan ajaran Bung karno, pendalaman pemahaman terhadap Pancasila, UUD NRI 1945, Bhineka Tunggal Ika, NKRI, pemahaman mengenai hak dan kewajiban warga negara Indonesia dalam membangun etika dan budaya politik.

Anggaran Dasar/Anggaran Rumah Tangga PPP pada Pasal 19 ayat (1) huruf(e) mengatur tentang tugas pengurus harian DPP, yaitu mengadakan latihan kepemimpinan kader utama (LKKU) paling sedikit dua kali dalam satu periode. Pasal 8 ayat (1) huruf (d) mengatur bahwa tugas pengurus harian DPW adalah mengadakan latihan kepemimpinan kader madya (LKKM) paling sedikit satu kali dalam satu periode. Pasal 36 ayat (1) huruf (d) menyatakan bahwa tugas pengurus harian DPC adalah mengadakan latihan kepemimpinan kader dasar (LKKD) paling sedikit satu kali dalam satu periode (PPP, 2016).

Partai memandang kaderisasi sebagai upaya mengubah potensi partai menjadi kekuatan nyata yang akan memperkokoh eksistensi partai dalam masyarakat. Sistem kaderisasi menurut PPP harus memerhatikan beberapa hal, yaitu: (a) kaderisasi PPP perlu dilakukan secara terencana, berjenjang, dan berkelanjutan, baik kaderisasi formal, informal, dan keahlian, serta dilakukan secara terpadu, (b) proses-proses politik dan partisipasi seseorang dalam kegiatan atau tugas-tugas kepartaian harus diletakkan sebagai bagian dari kaderisasi informal, (c) kaderisasi menggunakan sistem pelatihan kader secara berjenjang dan berkelanjutan pada semua tingkatan struktur partai, (d) menetapkan sistem rekrutmen kader yang potensial, baik dari segi kapasitas personal maupun pengaruh sosial dan politik, (e) mendorong, mempromosikan, dan memfasilitasi kader-kader partai agar dapat berperan di lembaga-lembaga politik dan segala bidang dalam kerja advokasi untuk memperkokoh kader partai di tengah masyarakat, (f) menyempurnakan buku tentang sistem dan pola pengaderan yang berkualitas pada aspek penjenjangan, peningkatan keahlian, metode, kurikulum, dan modul.

Peran partai politik menyelenggarakan pendidikan politik masih belum mendapatkan prioritas. AD/ART sebagai landasan partai menjalankan organisasi hanya memuat beberapa pasal mengenai pendidikan politik. Berdasarkan laporan pertanggungjawaban keuangan DPD PDIP Banten yang bersumber dari APBD Banten menunjukkan programprogram partai mengenai pendidikan politik masih jauh dari amanat $\mathrm{AD} / \mathrm{ART}$ atau peraturan perundang-undangan yang berlaku (PDIP, 2015b). Sebelum perubahan $\mathrm{AD} / \mathrm{ART}$ pada kongres terakhir, AD/ART PPP tidak mencantumkan secara spesifik 
mengenai pendidikan politik dan tidak memiliki wacana yang jelas mengenai proses kaderisasi di partai.

Perspektif bahwa partai politik dapat memberikan ruang transformasi sosial bagi masyarakat sebenarnya dapat tercermin dari proses penyelenggaraan tugas dan fungsinya sebagai penggerak demokrasi. Pemberian bantuan keuangan dari pemerintah dapat membantu partai untuk melaksanakan fungsinya secara maksimal. Berdasarkan laporan pertanggungjawaban keuangan yang bersumber dari APBD masih harus mendapatkan perhatian, khususnya terhadap penyelenggaraan pendidikan politik untuk dijadikan skala prioritas.

Pertanggungjawaban keuangan oleh partai politik dapat diukur berdasarkan perspektif substansi kinerja partai dengan menggunakan pendekatan akuntabilitas. Bantuan keuangan yang bersumber dari APBN dan APBD diprioritaskan untuk menyelenggarakan pendidikan politik dalam rangka penguatan demokratisasi di Indonesia. Laporan pertanggungjawaban agenda pendidikan politik tidak hanya untuk ketentuan persentase $60 \%$ akan tetapi lebih bertujuan untuk mewujudkan tujuan nasional. Partai politik yang terpilih punya kewenangan untuk merumuskan kebijakan yang berpengaruh terhadap seluruh rakyat.

\section{SIMPULAN}

Prosedur pertangguangjawaban keuangan partai politik yang bersumber dari APBN dan APBD diatur dalam Undang-Undang Nomor 2 Tahun 2011 tentang Perubahan Atas Undang-Undang Nomor 2 Tahun 2008 Tentang Partai Politik. Pertanggungjawaban keuangan menggunakan pendekatan akuntabel dan transparan. Penggunaan anggaran untuk pendidikan politik menurut peraturan minimal sebesar $60 \%$, sisanya adalah pembiayaan operasional kesekretariatan sebagaimana yang sudah diatur melalui Peraturan Pemerintah Nomor 83 Tahun 2012 tentang Perubahan Atas Peraturan Pemerintah Nomor 5 tahun
2009 tentang Bantuan Keuangan Kepada Partai Politik. Secara prosedural partai telah mempertanggungjawabkan keuangan tersebut kepada pemerintah dan telah diaudit oleh BPK. Partai sudah transparan yaitu dengan melaporkan pertanggungjawaban keuangannya kepada pemerintah dan masyarakat. Substansi pertanggungjawaban keuangan masih belum akuntabel, kegiatan kurang sesuai dengan landasan partai yang diatur dalam $\mathrm{AD} / \mathrm{ART}$ partai.

\section{DAFTAR RUJUKAN}

Asshiddiqie, J. (2017). Pengantar Ilmu Hukum Tata Negara. Jakarta: Rajawali Pers.

Asshiddiqie, J., \& Safa'at, M. A. (2012). Teori Hans Kelsen Tentang Hukum. Jakarta: Konstitusi Press.

Budiardjo, M. (2000). Dasar-dasar Ilmu Politik. Jakarta: Gramedia Pustaka Utama.

Cangara, H. (2011). Komunikasi Politik; Konsep, Teori dan Strategi Edisi Revisi. Jakarta: Rajawali Pers.

Departemen Pendidikan dan Kebudayaan. (1998). Kamus Besar Bahasa Indonesia. Jakarta: Penerbit Balai Pustaka.

DPD PDIP. (2015b). Laporan Pertanggungjawaban Dewan Perwakilan Daerah (DPD) Partai Demokrasi Indonesia Perjuangan (PDIP) Banten Tahun Anggaran 2015.

DPD PPP. (2015). Laporan Pertanggungjawaban Dewan Perwakilan Wilayah (DPW) Partai Persatuan Pembangunan (PPP) Banten Tahun Anggaran 2014.

Firdaus. (2015). Constitutional Engineering: Desain Stabilitas Pemerintahan Demokrasi dan Sistem Kepartaian. Bandung: Yrama Wedia.

Fokusmedia, T. R. (2009). Undang-Undang Politik. Bandung: Fokusmedia.

Halim, A., \& Syam, K. (2012). Akuntansi Sektor Publik. Jakarta: Salemba Empat. Keclime, M., \& Al, E. (1983). No Title. In Webster New Universal Umbridge 
Dictionary Second Edition. Simon Schuester.

Kusnardi, M., \& Harmaily, I. (1998). Pengantar Hukum Tata Negara Indonesia. Jakarta: Pusat Studi Hukum Tata Negara, Fakultas Hukum Universitas Indonesia dan CV Sinar Bakti.

Lukito, P. K. (2014). Membumikan Transparansi dan Akuntabilitas Kinerja Sektor Publik: Tantangan Berdemokrasi ke Depan. Jakarta: PT Gramedia Widiasarana Indonesia.

Manan, B. (2004). Teori dan Politik Konstitusi Cetakan Kedua. FH UII Press.

Nimmo, D. (2011). Komunikasi Politik (Komunikator, Pesan, dan Media) (Jalaluddin Rakhmat (ed.)). Bandung: PT. Remaja Rosdakarya.

PDIP. (2015a). Ketetapan Kongres IV PDIP. PPP. (2016). Ketetapan Muktamar VIII Partai Persatuan Pembangunan NO:07/ TAP/MUKTAMAR VIII/PPP/2016 Tentang Perubahan Anggaran Dasar dan Anggaran Rumah Tangga Partai Persatuan Pembangunan. https:// infopemilu.kpu.go.id/download/ verpol/119/ADART.pdf

Rahardjo, S. (2006). Ilmu Hukum. Bandung: Citra Aditya Bakti.

Republik Indonesia. (2011). Undang-
Undang Nomor 2 Tahun 2011 Tentang Perubahan Atas Undang-Undang Nomor 2 Tahun 2008 Tentang Partai Politik. LN Tahun 2011 Nomor 8, TLN Nomor 5189.

Rooseno. (2014). Akuntabilitas Pendanaan Partai Politik dalam Undang-Undang Nomor 2 Tahun 2011. Badan Pembinaan Hukum Nasional, Kementerian Hukum dan HAM RI

Soekanto, S. (1984). Pengantar Penelitian Hukum. Jakarta: Universitas Indonesia Press.

Sunaryo, A. (2014). Syafii Maarif: Pemilu Lalu Banyak Hasilkan Politisi Rabun Ayam. https://www.merdeka.com/ politik/syafii-maarif-pemilu-lalubanyak-hasilkan-politisi-rabun-ayam. html

Supriyanto, D., \& Wulandari, L. (2012). Bantuan Keuangan Partai Politik: Metode Penetapan Besaran, Transparansi, dan Akuntabilitas Pengelolaan (I). Jakarta: Yayasan Perludem. http://perludem.org/wpcontent/plugins/download-attachments/ includes/download.php?id=505

Surbakti, R. (1992). Memahami Ilmu Politik. Jakarta: PT Grasindo. 